\title{
Spelling Errors in Interlingual Subtitles: Do Viewers Really Mind?
}

\author{
Mikołaj Deckert \\ mikolaj.deckert@uni.lodz.pl \\ Institute of English Studies, \\ Department of Translation Studies and Language Pedagogy, \\ University of Łódź, Poland
}

\begin{abstract}
Our overarching objective is to see how unambiguous deficiencies in interlingual subtitles influence the viewing experience. To that end, we conducted a reception experiment in which participants viewed a foreign language film sample with subtitles which were manipulated across conditions for the number of spelling errors. We find that while viewers succeed in identifying spelling errors in subtitles, the presence of errors nonetheless generally has no effect on a range of viewer experience dimension like cognitive load, enjoyment, comprehension or transportation. What is more, while participants were able to make different subtitle authorship attributions (professional subtitler vs. amateur subtitler) depending on the presence of typos, deficient spelling did not shape the viewer's perception of the subtitler in terms of their estimated amount of experience or their diligence. Critically, the findings also indicate that typos have no effect on translation quality assessment scores which remain high even when there are as many as 20 typos in subtitles for a 14-minute clip. This work therefore offers new insights into translation reception with consequences for the didactic and professional settings. By embedding spelling errors in a dynamic and multimodal context where processing is not self-paced, the study importantly expands our understanding of how spelling errors are received, which has implications beyond translation studies as well.
\end{abstract}

Keywords: interlingual subtitling; spelling errors; cognitive processing; audiovisual content; reception

\section{INTRODUCTION}

Before we focus on spelling errors in interlingual subtitling, let us offer some broader background. To start with, research dealing with such linguistic deficiencies in writing could be naturally conceived of as two-pronged. First, it can be concerned with the 'production' component, concentrating for instance on language learning or difficulties (Siegel \& Mazabel 2014). The complementary perspective - one that is apparently less explored and is adopted in this paper - is to address the effect that deficiencies in written language have on facets of reception (e.g. Figueredo \& Varnhagen 2005). In this article we look into the role of spelling errors in subtitling - a mode of audiovisual translation (AVT) - which "may be described as a translation practice that consists of rendering in writing, usually at the bottom of the screen, the translation into a target language of the original dialogue exchanges uttered by different speakers as well as all other verbal information that appears written on-screen (letters, banners, inserts) or is transmitted aurally in the soundtrack (song lyrics, voices off)" (Díaz-Cintas 2020: 150). Subtitles function as one of the layers of multimodal input processed by viewers. Therefore, this paper aims to make a cognitively and linguistically oriented contribution to the dynamic field of AVT and media accessibility (MA). At the same time, the work reported in this paper provides new insights into the reception - and importantly, evaluation - of spelling errors in more general terms. Understanding the role of such linguistic flaws is ever-more 
topical given how much of our informal and professional language-mediated communication is written, whether in the form of texting, instant messaging or sending and reading e-mails.

\section{SPELLING ERROR RECEPTION ACROSS CONTEXTS}

As is signalled above, this paper draws together psychological inquiry into the reception of spelling errors, on the one hand, and inquiry into AVT/MA on the other hand.

\section{SPELLING ERRORS: RECEPTION AND BEHAVIOUR EFFECTS}

When it comes to the former, psychological research has already produced valuable insights into the role of spelling errors in cognition and consequently behaviour. Stiff (2012) identified effects of errors in the context of online consumer behaviour and attitudes. His studies looked into spelling and grammatical deficiencies in positive and negative written buyer comments on sellers, and found interesting effects. Errors in positive comments on a target affected participants' evaluation of the target. Then, the perception of the commenter was also negatively influenced when the comment was linguistically deficient. What is more, errors in positive feedback diminished how much a participant was ready to spend on goods offered by the target. Finally, trustworthiness of the source of a comment was negatively influenced by errors.

Martin-Lacroux and Lacroux (2017) designed a study focusing on spelling errors in job application forms. They conclude that deficient spelling influences the recruiter's choice as to whether to reject an application or invite a candidate for an interview, which is naturally moderated by the recruiter's own spelling ability. Even more remarkably, spelling was found to outweigh professional experience of candidates when it comes to employability, and the negative effect of spelling errors was greater where professional experience was greater. On the other hand, that research found no significant difference in applicant employability based on the number of spelling errors (5 or 10$)$.

In a related study Martin-Lacroux (2017) also used verbal protocols from recruiters assessing applicants. In the course of the research, she identified attributions that were grouped into three main categories: "soft skills" (e.g. "lacking in credibility and professionalism"), "abilities and competencies" (e.g. "intelligence" and "cultural capital" ("general culture"). That data lends credence to the idea that spelling (specifically spelling errors and typographical errors) can importantly influence impressions whereby the following input was elicited pointing to perception of candidates:

\footnotetext{
Rigor for this position is important from my point of view. For me, someone who send an application form like that is not someone rigorous.

Because someone who has spelling deficiency, who doesn't master the language skill as a result it may hide other deficiencies we can't assess immediately.

A spelling error may be interpreted as a lack of general education.
}

In another domain, a study by Boland and Queen (2016) probes the links between errors in e-mails from a potential housemate and how that potential housemate is evaluated. Their findings show that typos play a role in writer perception and - contrary to the authors' intuitions - typos were twice as consequential as what they call "grammos". Remarkably, the reader's reaction to errors was also individually shaped by the reader's personality. 


\section{EXTENDING THE SCOPE: AUDIOVISUAL TRANSLATION AND MEDIA ACCESSIBILITY}

While spelling errors have received a fair amount of scholarly attention in different contexts, no studies have so far been done into spelling errors in subtitles. This gap needs to be filled for two main reasons. First, it can shed new light on processing of deficient written language where it is not self-paced and where it operates as one of multiple meaning-making types of input accessed by the individual. In that sense the research presented in this article can contribute to the broader debate on spelling errors and cognition, especially that subtitle reading constitutes a large proportion of written text consumption for many individuals. Second, such research will benefit the scholarship on subtitling carried out by scholars engaging with AVT and MA. Better understanding of subtitling reception mechanisms can then feed into workflows and practices implemented by audiovisual content providers who rely on subtitling to a very large extent. This is all the more true if we acknowledge that official subtitles, like those available on streaming platforms, are intermittently accused of inferior quality, with typos serving as one of the more unambiguous cases. In that vein, it could be interesting to note that Netflix's streaming interface features a functionality that enables the user to report issues and one of the available categories is "Subtitles or captions problem" which is supposed to comprise issues like "Missing, hard to read, not matched with sound, misspellings or poor translations". For some reason, however, the relevant feedback from viewers has not always been used to eliminate flaws (Bargiel 2019: 67). Finally, in a broader perspective, it should be pointed out that subtitles constitute a large proportion of the written material consumed by users nowadays. This is particularly true for young people and once more underscores the need for making sense of how subtitles are processed.

When it comes to the status of AVT and MA, it is a relatively new academic field which has nonetheless already established itself as an exciting and promising area of study (cf. PérezGonzález 2018, Bogucki \& Deckert 2020). Within that area, interlingual subtitling research has been a major current. Naturally, subtitling research is in part motivated by the status of subtitles when it comes to users' foreign-language consumption preferences. From another angle, experimental work into subtitling is a rich source of insights into how multiple types of input are integrated by the receptor (cf. d'Ydewalle \& De Bruycker 2007) and findings can be extrapolated to inform inquiry into human cognition.

Subtitling has been investigated from a range of vantage points such as who creates the subtitles (e.g. Massidda 2015), what role technology plays in the process (e.g. Díaz-Cintas 2014), and how/what decisions are made by the subtitler across different types of problems ranging from compliments and forms of address to visualised metaphors and implicatures (e.g. Bruti 2006, Pedersen 2015, Szarkowska 2013, Desilla 2014). Notably, subtitling analyses have also been accommodated in different conceptual frameworks such as pragmatics (Bruti 2006, Guillot 2010, Desilla 2014), systemic functional linguistics (Kovačič 1996, Matielo et al. 2015), relevance theory (Braun 2016, Bogucki 2020), cognitive linguistics (Deckert 2013, Pedersen 2017a), or stylistics (McIntyre \& Lugea 2015, Hołobut et al. 2017), to name a few. Another important characteristic of subtitling research is the variety of methods that have been implemented to gauge both subtitle reception and subtitling production. These prominently include eye-tracking (for overviews see Kruger et al. 2015 as well as Kruger \& Doherty 2018: 97-101), and more recently electroencephalography (Kruger et al. 2016, Kruger et al. 2017).

This paper aims to provide new insights that fit into a very salient and fast-developing line of work on subtitling which has been concerned with how subtitles are processed by the viewers. Broadly seen, such studies could be comparing subtitles against other modes of AVT (e.g. Matamala et al. 2017), or examining the effect of differently designed subtitles (e.g. Szarkowska \& Gerber-Morón 2018, 2019), possibly considering various audiences (Perego et. al. 2015). 


\section{FOCUS AREAS}

The first dimension of the viewer experience we address is cognitive load (Plass et. al. 2010, Sweller et al. 2011). Since a word containing a particular case of a typo is less frequent than the well-formed counterpart (Boland \& Queen 2016), it seems intuitive to expect that a misspelled word will be more processing-intensive than the analogue with no typo. Testing cognitive load in subtitle processing has received scholarly attention but it is a fairly recent endeavour (Kruger et. al 2013).

A related dimension we investigated was enjoyment which was previously isolated as a construct in reception-oriented audiovisual translation research (e.g. Wissmath et al. 2009, Matamala et al. 2017). Enjoyment is seen as a multi-factor constructs drawing on physiology, affect as well as cognition (Davidson 2003) and can be broadly understood in terms of the approach and avoidance systems (Elliot \& Thrash 2002, Vorderer et al. 2004). Following Szarkowska \& Gerber-Morón (2018) who found that enjoyment was not affected either by the participants' mother tongue or subtitle speed, in our study we trace the influence of deficient spelling.

Analogously - coming to the third dimension we investigate in this study - it could be the case that with the limited time the viewer has to process input, misspelled subtitles could be processed in a way that affects comprehension. Given the allocation of attentional resources to the additional visual stimuli in the form of subtitles, which is not required of the source viewers, the target viewers would need to allocate less attention to other stimuli. The question is whether this diminished amount of attention affects comprehension. Earlier research into subtitle reception suggested subtitles can be processed with little detriment to comprehension (d'Ydewalle \& Gielen 1992, Perego et al. 2010, 2015) and subtitles can be processed effectively irrespective of the viewer's degree of acquaintance with this mode of AVT, as showed by the findings of a cross-national study by Perego et al. (2016). Likewise, Szarkowska \& Gerber-Morón showed that the viewers' subtitle processing capacity is larger than what might have been commonly assumed, and they presented evidence in support of the conclusion that "people could cope well with fast subtitle speeds and that they preferred them to slow ones in English clips" (Szarkowska \& Gerber-Morón 2018). Drawing on earlier empirical work, in this paper we aim to push the limits by testing the link between comprehension and subtitling based on what we hypothesise to be a resource-intensive case of subtitles with spelling errors.

The fourth dimension examined in the study is termed "transportation", based on the theory proposed by Green and Brock $(2000,2002)$, and defined as "a distinct mental process, an integrative melding of attention, imagery, and feelings" whereby "all mental systems and capacities become focused on events occurring in the narrative" (Green \& Brock 2000, p. 701). The construct of transportation metaphorically draws on the idea of physical travel (Gerrig 1993) or being "lost" in a story (Nell 1988). It is also broadly congruent with Csikszentmihalyi's (1997) construct of "flow". Another related notion is that of identification which Tal-Or and Cohen (2010, p. 406) distinguish from transportation as follows: "whereas transportation focuses on the degree of absorption and does not specify what it is in the narrative with which a reader or viewer is engaged, identification describes a strong attachment to a character indicated by seeing the character as positive and adopting his or her goals and perspective (...)". Keeping this conceptual distinction in mind, we should highlight MoyerGusé's point (2008, p. 409) that other terms have also been proposed to denote a construct much aligned with "transportation", such as "immersion" or "absorption" or "engrossment".

Given that a typo functions is a marked variant of a word, it could be that viewers register the markedness and are drawn out of the narrative to pay attention to the physical subtitle itself, which would be reflected in decreased transportation. This corresponds with the point that Green et al. (2004, p. 314) make about the desirability of transportation whereby they 
observe that "having one's attention unexpectedly diverted from a narrative in which one is engrossed - for instance, by fellow theatergoers talking audibly during a movie - is often sufficient to arouse one's ire, likely due to the fact that one was abruptly seized from the world to which one had been transported".

While the construct of transportation was first used to look into written narratives, the transition to audiovisual content is markedly made by Tal-Or \& Cohen (2010), and studies have already been reported looking into the relationship of transportation (and/or its kin constructs) and audiovisual content translation. To that end, Wissmath et. al (2009) were interested in the effect that the method of translation could have on presence, transportation, flow and enjoyment. Among other findings, they report that the degree of transportation (as well as of spatial presence and flow) is higher when a film is dubbed, as compared to when it is subtitled.

Finally, the study produces another set of insights into the relation between spelling errors and the viewer experience understood in terms of how viewers perceive the product and the producer. This meta-cognitive component was designed to offer another angle on the viewing experience but also to better contextualise findings from the other components of the study outlined above. To that end, importantly, it makes it possible to ascertain whether viewers in fact consciously registered spelling errors in subtitles. It also examines how much the presence and potential identification of typos is reflected in the participants' self-reported perception of the subtitler's professional and attitudinal status. Finally, this part of the study aims to answer the key question of whether typos are seen as constitutive of inferior product quality.

\section{THE STUDY}

\section{OBJECTIVES AND FOCI}

The study sets out to test whether unambiguous linguistic flaws in subtitles influence the viewing experience in the case of subtitled film. In other words, the question we are posing and trying to answer is: how much are subtitles constitutive of the viewing experience for foreignlanguage content, or - more specifically - whether or not subtitles of inferior quality are disruptive to the viewing experience.

To offer a comprehensive account, in this paper we deal with fundamental and interrelated dimensions that feed into the viewing experience. First, we look into degrees of cognitive load, enjoyment, comprehension as well as transportation. Then, the account is supplemented with insights into how participants perceived both the subtitles as well as the subtitler. For each of these dimensions we aim to ascertain the effect of misspelled subtitles.

The research is guided by the following research questions:

Q1: Will spelling errors in subtitles influence the viewer's cognitive load?

Q2: Will spelling errors in subtitles influence the viewers' enjoyment of subtitled film?

Q3: Will spelling errors in subtitles influence the viewer's comprehension of subtitled film?

Q4: Will spelling errors in subtitles influence the viewer's transportation?

\section{METHODOLOGY}

This primarily quantitative study is based on a reception experiment which employs audiovisual stimuli and written questionnaire-elicited input including participant self-reports. Therefore, the work methodologically fits into the line of AVT/MA research that is referred to as "reception studies" (Di Giovanni \& Gambier 2018). Reception studies and the experimental methodology construed more broadly have been gaining ground in translation and AVT/MA inquiries. Pertinently, in their position paper Orero et al. $(2018$, p. 119) voice the belief that 
"experimental research in AVT has the potential to elevate the field into a truly transdisciplinary, interdisciplinary and multidisciplinary endeavour that not only draws on other disciplines, but that strengthens other disciplines and expands our knowledge base in the humanities and the sciences".

\section{PARTICIPANTS, MATERIALS AND PROCEDURE}

The reception experiment involved a group of 62 participants, BA students at the Institute of English Studies in Łódź, Poland, 51 of whom were native speakers of Polish. Answers from this latter group are further analysed to ensure comparability since the subtitles were in Polish and the L1 vs. L2 parameter would need to be accounted for which goes beyond the current study. Within the pool of 51 participants 38 were female, 10 were male and 3 were non-binary, with a mean age of $21.37(\mathrm{SD}=1.66)$. When it comes to audiovisual translation preferences, a vast majority of participants $(90.2 \%)$ unambiguously declared subtitling was their mode of choice, one participant (2\%) stated he had no particular preferences for either of the modes, and one participant $(2 \%)$ stated he preferred subtitles but opted for voiceover "when [he felt] like resting [his] eyes and if the film [was] suitable for that". A mere 3 participants (6\%) stated voiceover was the mode of AVT they preferred.

Participants watched a 14-minute clip of the 2012 Thomas Vinterberg film "The Hunt" with subtitles displayed at the maximum rate of 18 characters per second. The rationale behind this choice of film was first of all that its language is Danish which was not spoken by any of our participants. This ensured that participants relied on subtitles for linguistic content rather than being able to retrieve content from the aural layer of the original film. Additionally, the film was chosen not to be commonly known to participants to maximise the reliability of results on comprehension. Participants were instructed to "watch it on the device [they] typically use to watch films for pleasure". Most watched the clip on a laptop (76.5\%), some used a desktop computer $(21.6 \%)$ and one person (less than $2 \%$ ) used a tablet. After watching the subtitled clip participants completed an online questionnaire comprising multiple choice and true/false type questions with a follow-up open question, as further detailed below.

Participants were randomly assigned to three conditions. The independent variable manipulated between conditions was the number of typos in subtitles that accompanied the clip. There were 168 one-line and two-line subtitles throughout the clip. In the "neutral" condition there were no typos. The "moderate" condition contained 10 errors, and the "extreme" condition had 20 of those. These were "typographical" misspellings (Kreiner et al. 2002) rather than "orthographic" ones. The reasoning behind this choice was not to use spelling errors that can be attributed to the writer's incompetence, i.e. declaratively not knowing the correct spelling. The errors we employed in the study are performance-based in the sense that the writer himself or herself would recognise the word with the spelling error to be malformed if they specifically allocated a sufficient amount of attention to that word. Employing typographical spelling errors that result from momentary lapses is likely to be taken as a weaker predictor of the subtitler's competence that what would be the case with the more 'stable' and 'intentional' errors resulting from insufficient knowledge of spelling conventions. In turn, these errors could be more likely attributed to insufficient diligence.

\section{RESULTS}

As mapped out above, the reception experiment addresses discernible while very much interrelated aspects of the viewing experience. The findings below will therefore be summarised following first the four categories of cognitive load, enjoyment comprehension, transportation, followed by the findings from the subtitling/subtitler perception component. 


\section{COGNITIVE LOAD}

Cognitive load was examined with the use of the following three indicators (Kruger et al. 2014, Szarkowska \& Gerber Morón 2018):

Was it difficult for you to read the subtitles in this clip? [difficulty]

Did you have to put a lot of effort into reading the subtitles in this clip? [effort]

Did you feel annoyed when reading the subtitles in this clip? [annoyance]

Participants responded to these questions on a 1-7 Likert-type scale. The results are presented in Table 1.

TABLE 1. Cognitive load indicators across conditions

\begin{tabular}{cccc}
\hline indicator & $\begin{array}{c}\text { neutral condition } \\
\text { M (SD) }\end{array}$ & $\begin{array}{c}\text { moderate condition } \\
\text { M (SD) }\end{array}$ & $\begin{array}{c}\text { extreme condition } \\
\text { M (SD) }\end{array}$ \\
\hline difficulty & $1.47(0.92)$ & $1.35(0.59)$ & $1.25(0.58)$ \\
effort & $1.33(0.49)$ & $1.55(0.89)$ & $1.44(0.89)$ \\
annoyance & $1.27(0.46)$ & $1.25(0.55)$ & $1.5(0.63)$ \\
\hline
\end{tabular}

First of all, it could be observed that the estimations for the 3 indicators are consistently low across conditions, suggesting that subtitle processing overall required little effort. This finding should be taken with a caveat that low cognitive load associated with subtitle processing does not necessarily mean low cognitive load associated with the processing of the clip which features subtitles. In other words, the clip with subtitles could be fairly processingintensive even if the accompanying subtitles are not, because the viewer expects the extra processing effort incurred by subtitles. Still, the low scores across conditions imply the subtitles did not incur more effort than what the participants expected based on their earlier experience with this mode of AVT. That this was the case in all three conditions is interesting and links to the questions of cross-condition differences. What we find is that there is no statistically confirmed difference in estimations of difficulty $(\mathrm{F}(2,48)=0.37, \mathrm{p}=0.69)$, effort $(\mathrm{F}(2,48)=$ $0.32, \mathrm{p}=0.73)$ or annoyance $(\mathrm{F}(2,48)=1.06, \mathrm{p}=0.35)$. This contradicts the intuitive hypothesis that an increased number of spelling errors in subtitles would result in higher degrees of experienced cognitive load.

\section{ENJOYMENT}

In line with earlier research (Wissmath et al. 2009, Szarkowska \& Gerber-Morón 2018, Kruger et al. 2017), enjoyment was probed with a Likert-type scale. We adapted the items developed by Tal-Or \& Cohen (2010). Importantly, these items are phrased in such a way as not to explicitly draw the respondents' attention to the subtitles but rather prompt them to gauge enjoyment of the viewing experience more generally, with subtitles operating as one component constitutive of that experience. As can be seen, viewer estimations were high, with a minimum mean of 4.5 on a 1-7 scale (Table 2). 
TABLE 2. Enjoyment indicators across conditions

\begin{tabular}{lccc}
\hline indicator & $\begin{array}{c}\text { neutral condition } \\
\text { M (SD) }\end{array}$ & $\begin{array}{c}\text { moderate condition } \\
\text { M (SD) }\end{array}$ & $\begin{array}{c}\text { extreme condition } \\
\text { M (SD) }\end{array}$ \\
\hline $\begin{array}{l}\text { I enjoyed the film } \\
\text { segment I watched in the } \\
\text { experiment very much. }\end{array}$ & $5.27(1.03)$ & $4.5(1.6)$ & $5.31(1.62)$ \\
$\begin{array}{l}\text { If this film is screened on } \\
\text { TV, I will watch it. }\end{array}$ & 5.33 & & 5.25 \\
$\begin{array}{l}\text { This is a movie that I can } \\
\text { enjoy. }\end{array}$ & $4.8(0.94)$ & 4.0 & $4.88(1.63)$ \\
\hline
\end{tabular}

For the first indicator no difference in self-reported enjoyment was found across the three conditions with $\mathrm{F}(2,48)=1.77, \mathrm{p}=0.18$. In the case of the second indicator, there is statistically confirmed difference with $F(2,48)=3.52, p=0.03$. Notably, the mean score is lowest for the median condition, which could be counter-intuitive. When it comes to the third indicator, the difference is not significant with $\mathrm{F}(2,48)=0.67, \mathrm{p}=0.52$. Therefore, we find little evidence to support the hypothesis that spelling errors adversely influence enjoyment.

\section{COMPREHENSION}

To obtain a more multifaceted account of the viewing experience, self-reports are combined with comprehension data. Drawing on the approach implemented in earlier studies (e.g. Perego et al. 2015, Szarkowska \& Gerber-Morón 2018), comprehension is operationalised as the success rate on questions related to the clip. Each participant responded to 10 items - with a multiple choice answer format (e.g. "What is the little girl's favourite dish?"; possible answers: lasagna, pizza, fish fingers, meatballs) or a binary yes/no choice (e.g. "Does the main character seem to be in good relations with his wife?", "Did Lucas use to work at a school some time ago?"). The success rate for the three conditions is presented in Table 3 below.

TABLE 3. Success rates for comprehension items across conditions

\begin{tabular}{cccc}
\hline $\begin{array}{c}\text { Item } \\
\text { no. }\end{array}$ & $\begin{array}{c}\text { neutral } \\
\text { condition }\end{array}$ & $\begin{array}{c}\text { moderate } \\
\text { condition }\end{array}$ & $\begin{array}{c}\text { extreme } \\
\text { condition }\end{array}$ \\
\hline 1. & $100 \%$ & $100 \%$ & $93.75 \%$ \\
2. & $100 \%$ & $90 \%$ & $100 \%$ \\
3. & $86.66 \%$ & $90 \%$ & $81.25 \%$ \\
4. & $86.66 \%$ & $80 \%$ & $75 \%$ \\
5. & $86.66 \%$ & $80 \%$ & $87.5 \%$ \\
6. & $100 \%$ & $95 \%$ & $93.75 \%$ \\
7. & $100 \%$ & $95 \%$ & $93.75 \%$ \\
8. & $93.33 \%$ & $85 \%$ & $100 \%$ \\
9. & $100 \%$ & $85 \%$ & $93.75 \%$ \\
10. & $80 \%$ & $70 \%$ & $87.5 \%$ \\
\hline
\end{tabular}

The mean comprehension scores are $93.33(\mathrm{SD}=7.70)$ in the neutral condition, 87.00 $(\mathrm{SD}=8.88)$ in the moderate condition and $90.63(\mathrm{SD}=7.93)$ in the extreme condition. There is no statistically confirmed difference in comprehension scores between the three conditions with $\mathrm{F}(2,27)=1.51, \mathrm{p}=0.24$. These findings are therefore at odds with the proposition that typos would affect viewer comprehension. 


\section{TRANSPORTATION}

For the construct of transportation we adapted the indicators from Tal-Or \& Cohen (2010). Participants were instructed to state on a 1-7 Likert-type scale how much they agreed/disagreed with each of the 7 statements (Table 4).

TABLE 4. Transportation indicators across conditions

\begin{tabular}{lccccc}
\hline \multicolumn{1}{c}{ Indicator/question } & $\begin{array}{c}\text { neutral } \\
\text { condition } \\
\text { M (SD) }\end{array}$ & $\begin{array}{c}\text { moderate } \\
\text { condition } \\
\mathbf{M} \text { (SD) }\end{array}$ & $\begin{array}{c}\text { extreme } \\
\text { condition } \\
\text { M (SD) }\end{array}$ & F & p \\
\hline $\begin{array}{l}\text { I could imagine myself } \\
\text { in the scenes I was }\end{array}$ & $3.53(1.88)$ & $2.6(1.57)$ & $2.94(1.95)$ & $\mathrm{F}=1.17$ & 0.32 \\
$\begin{array}{l}\text { watching. } \\
\begin{array}{l}\text { I was mentally involved } \\
\text { in the scenes I was } \\
\text { watching. }\end{array}\end{array}$ & $5.4(1.06)$ & $4.55(1.90)$ & $4.81(1.56)$ & $\mathrm{F}=1.25$ & 0.30 \\
$\begin{array}{l}\text { I would like to know } \\
\text { how the movie ends. }\end{array}$ & $6.0(1.36)$ & $5.15(2.08)$ & $6.13(1.63)$ & $\mathrm{F}=1.66$ & 0.20 \\
$\begin{array}{l}\text { The scenes affected me } \\
\text { emotionally. }\end{array}$ & $5.07(1.03)$ & $4.95(1.90)$ & $4.81(1.52)$ & $\mathrm{F}=0.10$ & 0.90 \\
$\begin{array}{l}\text { While watching, I was } \\
\text { thinking about what }\end{array}$ & $1.73(0.70)$ & $2.35(1.04)$ & $2.06(1.61)$ & $\mathrm{F}=1.18$ & 0.32 \\
$\begin{array}{l}\text { was going on in the } \\
\text { room I was in. }\end{array}$ & $2.27(0.88)$ & $2.65(1.60)$ & $2.5(1.46)$ & $\mathrm{F}=0.33$ & 0.72 \\
$\begin{array}{l}\text { After watching, I } \\
\text { stopped thinking about } \\
\text { the scenes I had been }\end{array}$ & & & & & \\
$\begin{array}{l}\text { watching. } \\
\begin{array}{l}\text { While viewing, my } \\
\text { mind wandered } \\
\text { (thinking about many } \\
\text { different things). }\end{array}\end{array}$ & $2.13(1.19)$ & $2.75(1.68)$ & $2.75(1.84)$ & $\mathrm{F}=0.78$ & 0.47 \\
\hline
\end{tabular}

As showed in Table 3, the number of spelling errors in subtitles had no significant effect on either of the seven indicators. It should be noted that as the transportation scores are not significantly different between conditions, these scores are consistently high.

\section{SUBTITLING AND SUBTITLER PERCEPTION}

The items in this component comprised two closely intertwined subcomponents, first shedding light on the subtitler and on then on the subtitles. The first subcomponent employed 3 items, with the first and the second one using a 1-7 Likert-type scale and the last one requiring participants to select one of 3 available variants.

\section{SUBTITLER EXPERIENCE}

In this item participants estimated the subtitler's amount of experience by replying to the question "How experienced is the subtitler?". The mean scores for the neutral, moderate and extreme conditions are: $5.33(1.05), 5(1.03)$ and $4.88(1.20)$. There is no statistically confirmed difference between conditions with $\mathrm{F}=0.73, \mathrm{p}=0.49$.

\section{SUBTITLER DILIGENCE}

For this indicator the following item phrasing was used: "How diligent is the subtitler?". The mean scores for the neutral, moderate and extreme conditions are here: 5.13 (1.13), 4.6 (1.05) 
and 4.69 (1.54). There is no statistically confirmed difference between conditions with $\mathrm{F}=$ $0.86, \mathrm{p}=0.43$.

\section{AUTHORSHIP ATRIBUTION}

To obtain input on the perception of the subtitler in a more indirect fashion we requested participants to state whether the subtitles they saw were produced by a professional or amateur subtitler. This draws on the premise that amateur translation will on average ${ }^{1}$ be associated with lower quality.

TABLE 5. Authorship attribution across conditions

\begin{tabular}{lccc}
\hline $\begin{array}{l}\text { Participants' authorship } \\
\text { attribution }\end{array}$ & neutral condition & $\begin{array}{c}\text { moderate } \\
\text { condition }\end{array}$ & $\begin{array}{c}\text { extreme } \\
\text { condition }\end{array}$ \\
\hline professional subtitler & $33.33 \%$ & $5 \%$ & $0 \%$ \\
hard to tell & $53.33 \%$ & $70 \%$ & $62.5 \%$ \\
amateur subtitler & $13.33 \%$ & $25 \%$ & $37.5 \%$ \\
\hline
\end{tabular}

Looking at the perceived 'professionalism' of the subtitler across conditions, we find significant differences between the neutral condition and the moderate condition $(Z=2.20, p$ $=0.03)$ and an even more pronounced difference between the neutral and extreme condition $(Z$ $=2.52, \mathrm{p}=0.01)$. In the case of the extreme condition it is notable that no participants recognised the producer to be a professional subtitler while in the moderate condition it was just one participant. This confirms that viewers in the experiment must have successfully identified the linguistic deficiencies and they served as the discerning parameter shaping the viewers' perception of the subtitler.

The second subcomponent concentrated on the perception of the product. This part of the study employed 1-7 Likert-type scales as well as a binary yes-no response format supplemented with an open follow-up question used to obtain additional justification in the case of positive answers.

\section{HOW WOULD YOU EVALUATE THE QUALITY OF THE SUBTITLES?}

The mean scores of overall subtitle quality are $5.53(0.83)$ in the neutral condition, $5.1(1.21)$ in the moderate condition, and $5.31(1.08)$ in the extreme condition. These scores are consistently high and there is no effect of spelling errors on the perception of subtitle quality with $\mathrm{F}(2,48)=0.71, \mathrm{p}=0.50$.

\section{WAS THERE ANYTHING YOU SPECIFICALLY NOTICED ABOUT THE SUBTITLING?}

In the neutral condition mere 2 participants $(13.33 \%)$ responded "yes" to the question. Interestingly, one of these observations was clearly positive: "I've noticed that the timing is really good. Sometimes, while I watch other movies the timing is a little bit off and this time it wasn't. But it's more of a technical issue." The other comment was about the possibly reductive trend in the subtitles: "That the subtitles were rather short. It almost felt like the subtitler was omitting a lot of the things that were said (not sure though, I don't know Danish)."

In the moderate condition 7 (35\%) participants agreed they noticed something specific. As many as 6 of the commenters $(30 \%)$ mentioned spelling ${ }^{2}$ (e.g. "Reoccurring spelling mistakes."), in one instance illustrating their observation with an example ("There was one

\footnotetext{
1 "Amateur" and "professional" are used here as heuristic shortcuts that rely on everyday - perhaps even stereotypical, and oftentimes unjust - supposition that amateur translations are of lower quality.

${ }^{2}$ One participant observed that "At times, there was a cyrillic K instead of the regular capital K." While this point is language-related, it is not categorised as a spelling error. An analogous point was brought up by a participant in the extreme condition but in that case this is not the exclusive point.
} 
mistake in the word "wrong"'"), and only one of the comments mentioned anything else in addition to typos, also giving the actual number of detected misspellings (" 2 spelling mistakes and nice short sentences").

In the extreme condition a total of 8 participants (50\%) gave an affirmative answer. Within that pool each participant pointed to spelling errors, sometimes additionally illustrating that observation (e.g. "Some typos like "karabni" instead of "karabin"'), and in two cases mentioning more parameters than spelling (e.g. "Some typos, and I had feeling that some of the subtitles did not match with what actors were speaking"). Remarkably, in two cases the participants offered positive evaluative statements alongside mentioning typos: "One or two spelling mistakes but generally the quality was very good." and "There were some typos in spelling. Except for that, the translation and its timing was good. At least, this is my humble opinion as someone who does not speak Danish."

The spelling error identification percentages for the three conditions are summarised in Figure 1 below. The difference in the proportions of participants who noticed spelling errors is significant in two-tailed two population proportions test between the neutral condition and both the remaining conditions $(Z=-2.33, p=0.02$ for neutral vs. moderate, and $Z=-3.18, p=0.001$ for neutral vs. extreme). These differences confirm that participants indeed noticed spelling errors in both of the conditions that used linguistically deficient subtitles.

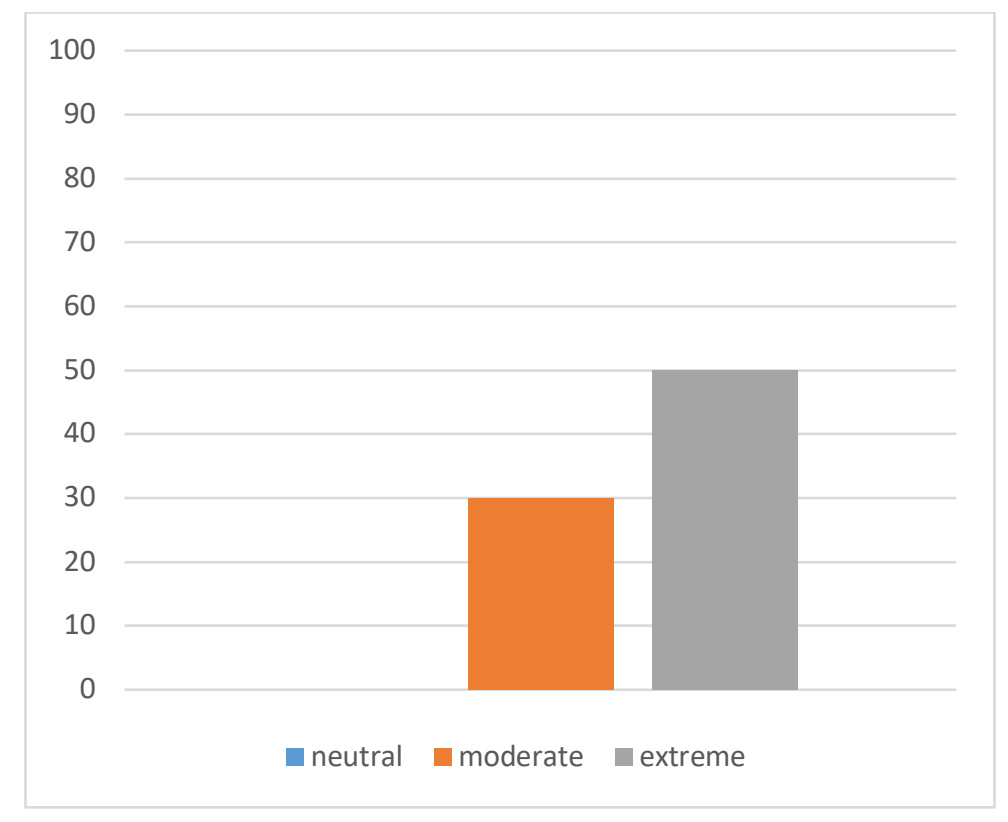

FIGURE 1. Spelling error identification across conditions without being explicitly asked (\%)

These findings can then be integrated with the responses from the next item that explicitly elicited feedback on typo identification in the subtitles.

\section{WERE THERE ANY TYPOS IN THE SUBTITLES?}

The mean scores for the degree of spelling error identification were 2.07 (1.03) in the neutral condition, 3.35 (1.39) in the moderate condition, and 3.5 (1.67) in the extreme condition. The difference is statistically significant with $F=5.01, p=0.01$ and corroborates the difference identified via the item that probed the link more indirectly. The increasing trend is showed graphically in Figure 2 below. 


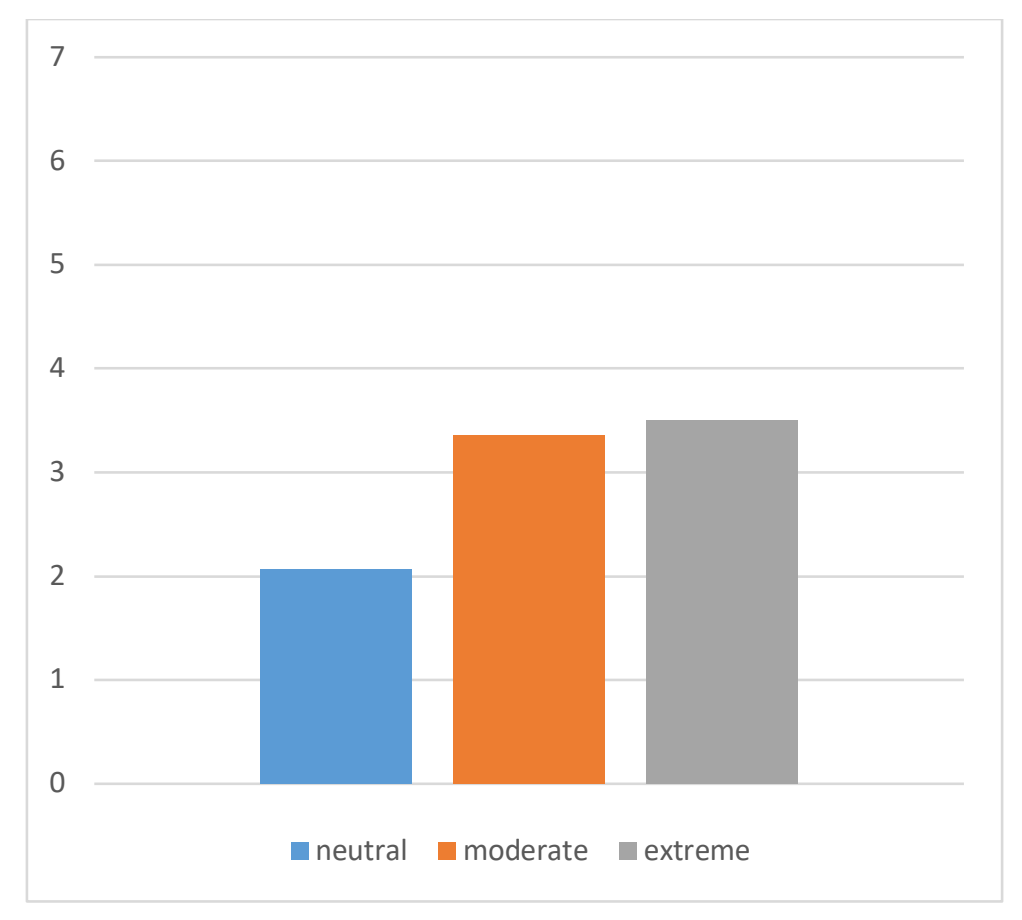

FIGURE 2. Spelling error identification across conditions when explicitly asked

\section{DISCUSSION OF FINDINGS AND CONCLUSION}

As reported above, the first key finding is that the number of spelling errors - ranging from 0 to 10 to 20 across experimental conditions - generally had no statistically confirmed influence on the viewing experience understood in terms of cognitive load, enjoyment, comprehension and transportation. The only case of statistically confirmed cross-condition difference was found for one of the indicators of enjoyment. These results critically need to be grounded with respect to the meta-cognitive component where feedback from participants was elicited on their perception of the subtitles and the subtitler. There, in contrast to what could be expected, we find that spelling errors in subtitles did not make the subtitler seem less experienced or less diligent. Similarly, and perhaps most counterintuitively, the perception of subtitle quality was not affected by the number of typos and remained high across conditions. At the same time, the results from the authorship attribution item show that typos made the viewers significantly less likely to state that the translation was produced by a professional subtitler. Subsequently, some even more direct evidence was obtained from two other items on whether viewers in the study were actually able to detect spelling errors. First, participants brought up spelling errors when asked about anything that attracted their attention in the subtitles. Then, when asked explicitly about typos in the subtitles, participants across conditions displayed significantly different typo identification rates.

Therefore, when it comes to the research questions (Q1 - Q4) formulated early in this paper, the answers that emerge from these results are clearly negative, and to a large extent unexpected. Overall, we find that participants indeed spotted typos but this had no traceable effect on either of the facets of reception that we examined in the study. An even more striking result is that viewers did not judge unambiguous linguistic deficiencies to be serious enough to influence overall subtitling quality negatively, even in the extreme condition which featured as many as 20 typos in a 14-minute film fragment. What is also notable, the mean score is arguably low given that it does not go beyond 3.5 - which is half of the available maximum - in the extreme condition. One way to account for this is that subtitles constitute too small a proportion of the incoming stimuli for subtitle manipulations to be easily reflected in cognitive processing. 
That is to say, the reception of subtitled film has to be viewed as a case of processing dynamic and complex multimodal input whereby subtitles are embedded alongside other layers, and it could be that the film's auditory and visual layers cognitively weigh in more on reception than subtitles. This would be consequential on many levels, and the observation can be further finetuned with other research instruments, perhaps most productively with eye-tracking. Another explanatory hypothesis to account for the viewers' remarkably positive assessment of subtitles with errors is that a fair amount of everyday non-professional linguistic communication that the participants engage in is conducted in writing with the use of a smartphone or a computer. In these communicative exchanges speed and efficiency are prioritised over formal impeccability - including typos - which means that the participants would have been exposed to cases of deficient linguistic form on a daily basis. That, in turn, could result in increased tolerance of those deficiencies and could explain, at least to some degree, why viewers in the experiment noticed typos but did not see them as a clear indicator of inferior quality.

The findings have implications for how we think about the viewer's processing capacity and preferences. If the subtitles that are specifically designed to incur extra effort - which was the case in our study - are processed with relative ease and with no detriment to comprehension, enjoyment or transportation, it seems there is some reserve of processing capacity in viewers and that reserve could be put to use. This argument is in line with the findings from research looking specifically into subtitling reception (Perego et al. 2010, Szarkowska \& Gerber-Morón 2018) as well as work that compared the reception of subtitling vis-à-vis dubbing (Matamala et al. 2017). While it is not to argue that the viewer's cognition should be invariably exploited to its limits, we wish to suggest that the opposite position - that of unconditionally minimising processing effort at the expense of other parameters - should not be unreflectively defaulted to. This holds implications for how translation companies, streaming services providers and filmmakers think about subtitling - and specifically about guidelines and their corresponding norms (cf. Pedersen 2020) - but could also feed into how subtitling is conceptualised by translation trainers, subtitlers and subtitling trainees.

On the whole, spelling errors have been seen as one of the key elements that detract from subtitling quality. For instance in Pedersen's (2017b) FAR model they receive a separate subcategory within "acceptability". Similarly, Szarkowska et al. (2020) talk about three "loose categories" of factors that can shape quality in subtitling whereby the second category comprises cases that "derive from the actual linguistic transfer, in which mishearings of the dialogue, excessive reduction in the original message, unorthodox line breaks, unwelcome presence of typos or infelicitous solutions that do not do justice to the source language or cultural reference." Given this status of spelling errors, our study sheds new light on the matter, highlighting the need for further empirical work investigating the links between spelling errors, reception and quality assessment in professional translators, proofreaders as well as stakeholders, as these links might be less straightforward than could be intuitively presumed. While the potential mismatches in quality perception across groups of receptors might eventually be found, a final caveat here should be that - given the findings of the study - it is none of this paper's intention to postulate that, other things being equal, spelling errors in subtitles should be monitored or evaluated less strictly in some cases than in others.

\section{REFERENCES}

Bargiel, E. (2019). An Audiovisual Translation Assessment of the Quality Assurance System at Netflix. Unpublished MA thesis. University of Łódź.

Bogucki (2020). A Relevance-Theoretic Approach to Decision-Making in Subtitling. Palgrave Macmillan: London. 
Bogucki, Ł. \& Deckert, M. (eds.) (2020). The Palgrave Handbook of Audiovisual Translation and Media Accessibility. Palgrave Macmillan: Basingstoke.

Boland J. E. \& Queen R. (2016). "If You're House Is Still Available, Send Me an Email: Personality Influences Reactions to Written Errors in Email Messages". PLoS ONE 11(3), e0149885.

Braun, S. (2016). The importance of being relevant?: A cognitive-pragmatic framework for conceptualising audiovisual translation. Target. International Journal of Translation Studies, 28(2), 302-313.

Bruti, S. (2006). Cross-cultural pragmatics: The translation of implicit compliments in subtitles. JoSTrans: The Journal of Specialised Translation, 6, 185-197.

Csikszentmihalyi, M., 1997. Finding Flow: The Psychology of Engagement with Everyday Life. Basic Books, New York.

Davidson, R. J. (2003). Seven sins in the study of emotion: Correctives from affective neuroscience. Brain and Cognition, 52, 129-132.

Deckert, M. (2013). Meaning in Subtitling: Toward a Contrastive Cognitive Semantic Model. Peter Lang: Frankfurt am Main.

Desilla, L. (2014). "Reading between the lines, seeing beyond the images: An empirical study on the comprehension of implicit film dialogue meaning across cultures." The Translator, 20(2), 194-214.

Díaz-Cintas, J. (2020). "The name and nature of subtitling". In Ł. Bogucki \& M. Deckert (Eds.), The Palgrave Handbook of Audiovisual Translation and Media Accessibility. Palgrave Macmillan: Basingstoke.

Díaz-Cintas, J. (2014). “Technological strides in subtitling”. In Ch. Sin-wai (Ed.), The Routledge Encyclopedia of Translation Technology (pp. 670-681). Routledge.

Di Giovanni, E. \& Gambier, Y. (eds.) (2018). Reception Studies and Audiovisual Translation. Amsterdam: John Benjamins.

d'Ydewalle, G., \& Gielen, I. (1992). Attention allocation with overlapping sound, image, and text. In K. Rayner (Ed.), Eye movements and visual cognition: Scene perception and reading (pp. 415-427). New York: Springer-Verlag.

d'Ydewalle, G., \& De Bruycker, W. (2007). Eye movements of children and adults while reading television subtitles. European Psychologist, 12, 196-205.

Elliot, A. J., \& Thrash, T. M. (2002). Approach-avoidance motivation in personality: Approach and avoidance temperament and goals. Journal of Personality and Social Psychology, $82,804-818$.

Figueredo, L., \& Varnhagen, C. K. (2005). Didn't you run the spell checker? Effects of type of spelling error and use of a spell checker on perceptions of the author. Reading Psychology, 26(4-5), 441-458.

Gerrig, R. J. (1993). Experiencing narrative worlds. New Haven, CT: Yale University Press.

Green, M. C., \& Brock, T. C. (2000). The role of transportation in the persuasiveness of public narratives. Journal of Personality and Social Psychology, 79, 701-721.

Green, M. C., \& Brock, T. C. (2002). In the mind's eye: Transportation-imagery model of narrative persuasion. In M. C. Green, J. J. Strange, \& T. C. Brock (Eds.), Narrative impact: Social and cognitive foundations (pp. 315-341). Mahwah, NJ: Erlbaum.

Green, M. C., Brock, T. C. \& Kaufman, G. F. (2004). "Understanding Media Enjoyment: The Role of Transportation Into Narrative Worlds", Communication Theory, 14(4), 311327 ,

Guillot, M.-N. (2010). Film subtitles from a cross-cultural pragmatics perspective. The Translator, 16(1), 67-92. 
Hołobut, A, Woźniak, M. \& Rybicki, J. (2017). “Old questions, new answers: computational stylistics in audiovisual translation research". In M. Deckert (Ed.), Audiovisual translation: research and use, Frankfurt am Main (pp. 203-216) Peter Lang.

Kovačič, I. (1996). "Subtitling strategies: a flexible hierarchy of priorities". In: C. Heiss and R.M. Bollettieri Bosinelli (eds.). Traduzione multimediale per il cinema, la televisione e la scena, p. 297-305. Bologna: Clueb.

Kreiner, D. S., Schnakenberg, S. D., Green, A. G., Costello, M. J., \& McClin, A. F. (2002). Effects of spelling errors on the perception of writers. The Journal of general psychology, 129(1), 5-17.

Kruger, J. L., Doherty, S., \& Soto-Sanfiel, M. T. (2017). Original language subtitles: Their effects on the native and foreign viewer. Comunicar. Media Education Research Journal, 25(1).

Kruger, J. L., Soto-Sanfiel, M. T., Doherty, S., \& Ibrahim, R. (2016). Towards a cognitive audiovisual translatology. Reembedding Translation Process Research. Amsterdam: John Benjamins, 171-194.

Kruger J. L., Hefer E., Matthew G. (2014). Attention distribution and cognitive load in a subtitled academic lecture: L1 vs. L2. Journal of Eye Movement Research, 7(5), 4, 115.

Kruger, J. L., Hefer, E., \& Matthew, G. (2013). Measuring the impact of subtitles on cognitive load: Eye tracking and dynamic audiovisual texts. In Proceedings of the 2013 Conference on Eye Tracking South Africa (pp. 62-66).

Kruger, J. L., Szarkowska, A., \& Krejtz, I. (2015). Subtitles on the moving image: an overview of eye tracking studies. Refractory: A Journal of Entertainment Media, 25, 1-14.

Kruger, J. L, Doherty, S., Fox, W. \& de Lissa, P. (2017). "Multimodal measurement of cognitive load during subtitle processing: Same-language subtitles for foreign language viewers". in: I. Lacruz and R. Jääskeläinen (eds). Innovation and Expansion in Translation Process Research, Amsterdam/Philadelphia: John Benjamins, 267-294.

Kruger, J. L., \& Doherty, S. (2018). Triangulation of online and offline measures of processing and reception in AVT. In E. Di Giovanni and Y. Gambier (eds.) Reception studies and audiovisual translation. John Benjamins, 91-110.

Martin-Lacroux, C. (2017). '“Without the Spelling Errors I Would Have Shortlisted Her...': The Impact of Spelling Errors on Recruiters' Choice During the Personnel Selection Process", International Journal of Selection and Assessment, 25(3),276-283.

Martin-Lacroux, C., \& Lacroux, A. (2017). Do employers forgive applicants' bad spelling in résumés?. Business and Professional Communication Quarterly, 80(3), 321-335.

Massidda, S. (2015). Audiovisual translation in the digital age: The Italian fansubbing phenomenon. Palgrave Macmillan: Basingstoke.

Matamala, A., Perego, E., \& Bottiroli, S. (2017). Dubbing versus subtitling yet again?: An empirical study on user comprehension and preferences in Spain. Babel, 63(3), 423441.

Matielo, R., de Vasconcellos, M. L. B. \& Espindola Baldissera, E. (2015). "Subtitling words or omitting worlds? A metafunctionally-oriented analysis", Revista de Estudos da Linguagem, 23(2). 363-388.

McIntyre, D. \& Lugea, J. (2015) The effects of deaf and hard-of-hearing subtitles on the characterisation process: a cognitive stylistic study of The Wire, Perspectives, 23(1), 62-88.

Moyer-Gusé, E., (2008). Toward a theory of entertainment persuasion: explaining the persuasive effects of entertainment-education messages. Communication Theory, 18, 407-425. 
Nell, V. (1988). Lost in a book: The psychology of reading for pleasure. New Haven, CT: Yale University Press.

Orero, P., Doherty, S., Kruger, J. L., Matamala, A., Pedersen, J., Perego, E., Romero-Fresco, P., Rovira-Esteva, S., Soler-Vilageliu, O., Szarkowska, A. (2018). "Conducting experimental research in audiovisual translation (AVT): A position paper". JoSTrans: The Journal of Specialised Translation, 30, 105-126.

Pedersen, J. (2020). "Audiovisual translation norms and guidelines", in Ł. Bogucki \& M. Deckert (eds.) The Palgrave Handbook of Audiovisual Translation and Media Accessibility. Palgrave Macmillan: London.

Pedersen, J. (2017a). "How metaphors are rendered in subtitles", Target, 29(3), 416-439.

Pedersen, J. (2017b). The FAR Model: Assessing Quality in Interlingual Subtitling. JoSTrans: The Journal of Specialised Translation, 28, 210-229.

Pedersen, J. (2015). "On the subtitling of visualised metaphors", JoSTrans: The Journal of Specialised Translation, 23, 162-180.

Perego, E., Del Missier, F., Porta, M. \& Mosconi, M. (2010). The Cognitive Effectiveness of Subtitle Processing, Media Psychology, 13(3), 243-272.

Perego, E., Del Missier, F., \& Bottiroli, S. (2015). Dubbing versus subtitling in young and older adults: Cognitive and evaluative aspects. Perspectives, 23(1), 1-21.

Perego, E., Laskowska, M., Matamala, A., Remael, A., Robert, I.S., Szarkowska, A., Vilaró, A. and Bottiroli, S., (2016). "Is subtitling equally effective everywhere? A first crossnational study on the reception of interlingually subtitled messages", Across Languages and Cultures, 17(2), 205-229.

Pérez-González, L. (2018). The Routledge Handbook of Audiovisual Translation. Routledge: London and New York.

Plass, J. L., Moreno, R., \& Brünken, R. (Eds.). (2010). Cognitive load theory. Cambridge: Cambridge University Press.

Siegel, L. S., \& Mazabel, S. (2014). Basic cognitive processes and reading disabilities. In H. L. Swanson, K. R. Harris, \& S. Graham (Eds.), Handbook of learning disabilities, The Guilford Press, 186-213.

Stiff, C. (2012). Watch what you write: How errors in feedback influence consumer attitudes and behavior. Journal of Internet Commerce, 11(1), 41-67.

Sweller, J., Ayres, P., \& Kalyuga, S. (2011). Cognitive load theory. New York: Springer.

Szarkowska, A. (2013) Forms of Address in Polish-English Subtitling. Frankfurt am Main: Peter Lang.

Szarkowska, A. \& Gerber-Morón, O. (2019). "Two or three lines: a mixed-methods study on subtitle processing and preferences". Perspectives: Studies in Translation Theory and Practice, 27(1), 144-164.

Szarkowska A. \& Gerber-Morón O (2018). Viewers can keep up with fast subtitles: Evidence from eye movements. PLoS ONE, 13(6), e0199331.

Szarkowska, A., Díaz Cintas, J. \& Gerber-Morón, O. (2020). Quality is in the eye of the stakeholders: what do professional subtitlers and viewers think about subtitling?. Universal Access in the Information Society.

Tal-Or, N. \& Cohen, J. (2010). "Understanding audience involvement: Conceptualizing and manipulating identification and transportation", Poetics, 38, 4, 402-418.

Vorderer, P., Klimmt, C., \& Ritterfeld, U. (2004). Enjoyment: At the heart of media entertainment. Communication theory, 14(4), 388-408.

Wissmath, B., Weibel, D., \& Groner, R. (2009). Dubbing or subtitling? Effects on spatial presence, transportation, flow, and enjoyment. Journal of Media Psychology, 21(3), 114-125. 
APPENDIX A

THE MODERATE CONDITION: 10 SPELLING ERRORS IN SUBTITLES

\begin{tabular}{lll}
\hline $\begin{array}{c}\text { Subtitle } \\
\text { number }\end{array}$ & \multicolumn{1}{c}{ Correct spelling } & \multicolumn{1}{c}{ Misspelling } \\
\hline 5 & - Założyli się o 1200 koron. & - Załozyli się o 1200 koron. \\
41 & - Że co? & - Że co? \\
& - Wszystko ok? & - Wszystko ok? \\
52 & - Zabłądziłam. & - Zabładziłam. \\
& - Fanny pójdzie z nami? & - Fanny pójdzie z nami? \\
58 & - Oczywiście. & - Oczwiście. \\
& Byłem nauczycielem & Byłem nauczycielem \\
78 & w szkole twojego brata, & W szkole twoego brata, \\
& - Cześć, Lucas! & - Cześć, Lucas! \\
95 & - Cześć, Agnes. & - Czesć, Agnes. \\
108 & Jak sprawy z Marcusem i twoją byłą? & Jak sparwy z Marcusem i twoją byłą? \\
& - Połóż się brudny kundlu! & - Polóż się brudny kundlu! \\
123 & - Przestań. & - Przestań. \\
\multirow{2}{*}{162} & Jak mam z tobą rozmawiać, & Jak mam z tobą rozmawiać, \\
& skoro ty nie dzwonisz i ja tėż nie mogę. & skoro ty nie dzwownisz i ja też nie mogę. \\
& To chyba ktoś z ciebie zażartował. & To chyba ktoś z ciebie zażartowawł. \\
& To nie ode mnie. & To nie ode mnie. \\
\hline
\end{tabular}




\section{APPENDIX B}

THE EXTREME CONDITION: 20 SPELLING ERRORS IN SUBTITLES

\begin{tabular}{|c|c|c|}
\hline $\begin{array}{l}\text { Subtitle } \\
\text { number }\end{array}$ & Correct spelling & Misspelling \\
\hline 5 & $\begin{array}{l}\text { - Założyli się o } 1200 \text { koron. } \\
\text { - Że co? }\end{array}$ & $\begin{array}{l}\text { - Załozyli się o } 1200 \text { koron. } \\
\text { - Że co? }\end{array}$ \\
\hline 15 & Mamy na brzegu wieloryba. & Mamy na brzegu wielorbya. \\
\hline & Trzeba mu zrobić masaż serca, Theo. & Trzeba mu zrobić masaż serca, Theo. \\
\hline 27 & $\begin{array}{l}\text { - Potrzebuję do toalety! } \\
\text { - Powieście kurtki. }\end{array}$ & $\begin{array}{l}\text { - Potrzebuję do toalety! } \\
\text { - Powiescie kurtki. }\end{array}$ \\
\hline 41 & $\begin{array}{l}\text { - Wszystko ok? } \\
\text { - Zabłądziłam. }\end{array}$ & $\begin{array}{l}\text { - Wszystko ok? } \\
\text { - Zabładziłam. }\end{array}$ \\
\hline 48 & To kiepsko. & To kiespsko. \\
\hline 49 & $\begin{array}{l}\text { Ja znam drogę. } \\
\text { Pójdziemy razem? }\end{array}$ & $\begin{array}{l}\text { Ja znam drogę. } \\
\text { Pojdziemy razem? }\end{array}$ \\
\hline 52 & $\begin{array}{l}\text { - Fanny pójdzie z nami? } \\
\text { - Oczywiście. }\end{array}$ & $\begin{array}{l}\text { - Fanny pójdzie z nami? } \\
\text { - Oczwiście. }\end{array}$ \\
\hline 57 & Dlaczego pracujesz w przedszkolu? & Dlaczego parcujesz w przedszkolu? \\
\hline 58 & Byłem nauczycielem & Byłem nauczycielem \\
\hline 73 & $\begin{array}{l}\text { W szkole twojego brata, } \\
\text { Kochanie, } \\
\text { mówiłem ci, żebyś się pilnowała. }\end{array}$ & $\begin{array}{l}\text { W szkole twoego brata, } \\
\text { Kochanie, } \\
\text { mówiłem ci, żbyś się pilnowała. }\end{array}$ \\
\hline 78 & $\begin{array}{l}\text { - Cześć, Lucas! } \\
\text { - Cześć, Agnes. }\end{array}$ & $\begin{array}{l}\text { - Cześć, Lucas! } \\
\text { - Czesć, Agnes. }\end{array}$ \\
\hline 82 & Twój karabin też wala się po domu? & Twój karabini też wala się po domu? \\
\hline 90 & $\begin{array}{l}\text { - Kiedy do nas wpadniesz? } \\
\text { - Mogę w środę. }\end{array}$ & $\begin{array}{l}\text { - Kiedy do nas wpadniesz? } \\
\text { - Mogę w srodę. }\end{array}$ \\
\hline 95 & Jak sprawy z Marcusem i twoją byłą? & Jak sparwy z Marcusem i twoją byłą? \\
\hline 108 & $\begin{array}{l}\text { - Połóż się brudny kundlu! } \\
\text { - Przestań. }\end{array}$ & $\begin{array}{l}\text { - Polóż się brudny kundlu! } \\
\text { - Przestań. }\end{array}$ \\
\hline 116 & Masz 42 lata i pracujesz w przedszkolu. & Masz 42 lata i pracujsz w przedszkolu. \\
\hline 123 & $\begin{array}{l}\text { Jak mam z tobą rozmawiać, } \\
\text { skoro ty nie dzwonisz i ja też nie mogę. }\end{array}$ & $\begin{array}{l}\text { Jak mam } z \text { tobą rozmawiać, } \\
\text { skoro ty nie dzwownisz i ja też nie mogę. }\end{array}$ \\
\hline 159 & Daj to może któremuś chłopcu. & Daj to moze któremuś chłopcu. \\
\hline 162 & $\begin{array}{l}\text { To chyba ktoś z ciebie zażartował. } \\
\text { To nie ode mnie. }\end{array}$ & $\begin{array}{l}\text { To chyba ktoś } z \text { ciebie zażartowawł. } \\
\text { To nie ode mnie. }\end{array}$ \\
\hline
\end{tabular}

\section{ABOUT THE AUTHOR}

Mikołaj Deckert is associate professor at the University of Łódź, Institute of English Studies, in Poland. In his research he uses experimental and corpus methods to look into language and cognition as well as interlingual translation. He recently co-edited "The Palgrave Handbook of Audiovisual Translations and Media Accessibility" (2020). 